\title{
Growth response of spruce saplings in relation to climatic conditions along a gradient of gap size
}

\author{
Igor Drobyshev and Bengt Nihlgård
}

\begin{abstract}
To evaluate the relative importance of climatic factors and the level of natural canopy disturbance on sapling growth rates, terminal shoot increment of Norway spruce (Picea abies (L.) Karst.) saplings was analyzed in old-growth Sphagnum-Myrtillus forests of the European southern boreal zone (Tver Region, Russia). For a 5-year period, terminal increments were retrospectively measured in 225 saplings in a range of naturally created canopy gaps. Climatic variability was estimated by Seljaninov hydrothermal coefficient. Variation in the growth rate was partitioned as $(i)$ annual variation observed within a particular sapling over a 5-year period ("within-stem variation," WSV) and (ii) variation of 5-year cumulative height increments within a particular location ("within-location variation," WLV). Sapling growth was positively related to gap size and, except when under canopy location, with the height of the saplings. For the growth, differences in sapling location along a gradient of gap sizes were more important than annual dynamics of water availability. Impact of the annual climatic variability was less pronounced in large gap, compared with other locations. Absolute values of WSV and WLV were similar under an intact canopy. WSV had a tendency to decrease in greater gaps, whereas WLV variation increased.
\end{abstract}

Résumé : Pour évaluer l'importance relative des facteurs climatiques et le niveau de perturbation du couvert naturel sur le taux de croissance des gaules, l'accroissement de la pousse terminale des gaules de l'épicéa commun (Picea abies (L.) Karst.) a été analysé dans de vieilles forêts du type Sphagnum-Myrtillus de la partie sud de la zone boréale européenne (région de Tver en Russie). L'accroissement terminal a été mesuré rétrospectivement sur une période de 5 ans chez 225 gaules, réparties dans une gamme d'ouvertures naturelles du couvert. La variabilité climatique a été estimée par le coefficient hydrothermique de Seljaninov. La variation du taux de croissance a été divisée $(i)$ en variation annuelle observée chez une gaule particulière sur une période de 5 ans ("variation intra-tige," VIT) et (ii) en variation de l'accroissement cumulatif en hauteur, sur une période de 5 ans, à l'intérieur d'un site particulier ("variation intrasite," VIS). La croissance des gaules était reliée positivement avec la dimension des ouvertures et, sauf dans le cas des sites sous couvert, avec la hauteur des gaules. Pour ce qui est de la croissance, les différences dans la position des gaules le long d'un gradient dans la dimension des ouvertures étaient plus importantes que la dynamique annuelle de la disponibilité en l'eau. L'impact de la variabilité climatique annuelle était moins prononcé dans les grandes ouvertures que dans d'autres sites. Sous un couvert intact, les valeurs absolues de VIT et de VIS étaient semblables. La valeur de VIT avait tendance à diminuer dans les grandes ouvertures, alors que la variation de VIS augmentait.

[Traduit par la Rédaction]

\section{Introduction}

Differences in the levels of environmental factors between shaded understorey and a canopy gap appear to be a major source of variation in sapling growth rates, both for shadeintolerant (Canham 1988; Busing and White 1997) and shadetolerant species (Tucker et al. 1997). Higher growth rates of saplings in gaps, compared with those under a closed canopy, make such patches important for tree regeneration in many temperate and tropical forests (e.g., Runkle 1985;

Received April 8, 1999. Accepted December 3, 1999.

I. Drobyshev. ${ }^{1}$ SUFOR Project, Lund University, Sweden and Laboratory of Bird Ecology and Protection, Biological

Institute, St. Petersburg State University, Oraninbaumskoe

shosse 2, St. Petersburg, 198904, Russia.

e-mail: Igor.Drobyshev@planteco.lu.se and

igor@area.usr.pu.ru

B. Nihlgård. SUFOR Project, Department of Plant Ecology,

Ecology Building, Sölvegatan 37, Lund University, S-223 62

Lund, Sweden. e-mail: Bengt.Nihlgard@planteco.lu.se

${ }^{1}$ Corresponding author.
Veblen 1986; Hytteborn et al. 1987; Platt and Strong 1989). At the same time, growth rates may also be influenced by variation in climatic conditions, which are believed to be important determinants of tree growth (e.g., Fritts 1974; Villalba et al. 1992; Schweingruber 1993; Clark and Clark 1994; Abrams and Orwig 1995; Ettl and Peterson 1995).

The interaction between canopy disturbance leading to gap formation and climate could be critical for the canopy composition, because it could directly affect tree growth (Hofgaard et al. 1991), change the species susceptibility to other disturbance agents (Clinton et al. 1993), affect the rate and pattern of vegetation recovery within a disturbed area (Rebertus and Burns 1997), and (or) influence the sapling's chances of reaching the forest canopy within particular types of disturbed patches (Canham and Marks 1985). Furthermore, within a longer period of time, changes in climate could alter the relative success of disturbance-mediated regeneration of different species (e.g., Hogg 1994; Savage et al. 1996; Sykes and Prentice 1996, and references therein).

Despite numerous studies of tree response to climatic variation (Fritts 1974; Devall et al. 1991; Hofgaard et al. 1991; Villalba and Veblen 1994; Frolking et al. 1996; Piutti 
and Cescatti 1997; Swetman and Betancourt 1998) and interactions of climate with other disturbance agents (Swetnam and Lynch 1993; Zhang et al. 1999), surprisingly few attempts have been made to analyze the combined effect of natural canopy disturbance and climate on sapling growth. There are indications for some coniferous species that the response to climatic variation may vary along gradients of environmental factors (Villalba and Veblen 1994; Orwig and Abrams 1997) and competitive interference (Piutti and Cescatti 1997). The role of temperature and precipitation in controlling growth of saplings was considered while looking for differences in sapling growth between gap and understory (e.g., Sipe and Bazzaz 1995; Veenendaal et al. 1996; Maherali et al. 1997) and, in particular, when considering the effect of gap partitioning (Wayne and Bazzaz 1993; Gray and Spies 1996). However, to our knowledge, there have been no studies assessing the impact of yearly variation in regional climatic characteristics on the sapling growth along a size gradient of naturally created canopy disturbances.

The yearly variation in sapling growth originates from three principal sources: $(i)$ changes in site properties over time, including changes in microclimate, soil properties and competitive interactions; (ii) age- and height-related changes in growth potential; and (iii) year-to-year variation in climate, levels of pathogen infection, and (or) herbivore damage.

One might suggest several ways in which disturbance could interact with the yearly variation in climate in determining the sapling growth pattern. Compared with a sampling under a closed canopy, a sapling in a gap is more exposed to climatic variations. Thus, the annual growth may vary more as the area of the disturbed patch increases. In other words, gap size can have a dual effect on sapling growth: firstly, through changes in the amplitude of variation of environmental factors and, secondly, by direct control of resource availability (e.g., light and nutrients).

Differences in the degree of fluctuation of environmental factors is also likely to affect the pattern of growth variation of saplings. The latter can be partitioned into $(i)$ annual variability among saplings in a particular location and (ii) variation in the growth rate of a sapling over a period of years. Since the resource availability and growth rate generally change in a linear fashion along the gradient of disturbance size (e.g., Yetter and Runkle 1986), it would be possible for the two components of growth variation to show a certain linear pattern along a disturbance gradient. To test these assumptions, the growth of Norway spruce (Picea abies (L.) Karst.) saplings was retrospectively studied in old-growth Sphagnum-Myrtillus spruce-dominated forests under intact canopy and in a range of natural treefall gaps.

\section{Hypotheses}

Three hypotheses about sapling growth patterns were combined into two groups.

\section{Relative importance of different factors}

(1) Different levels of canopy disturbance are more important than annual growth variability.

\section{Interactions between gap size and annual growth} variability

(2) The relationship between yearly terminal growth and environmental characteristics is more pronounced in greater disturbed community patches, i.e., the strength of correlation between growth and water availability increases with the size of gaps.

(3) There is a consistent pattern of growth variation among saplings along a gradient of gap sizes.

\section{Study site}

The study was conducted in the old-growth Sphagnum-Myrtillus forests of the Central Biosphere State Forest Reserve, Tver region, Russia $\left(32^{\circ} 29^{\prime}-33^{\circ} 01^{\prime} \mathrm{E}, 56^{\circ} 26^{\prime}-56^{\circ} 31^{\prime} \mathrm{N}\right)$. The area lies in the southern taiga (south boreal) subzone of the taiga zone (Sochava 1956). The reserve is located on the poorly drained main CaspianBaltic watershed of the Russian Plain, in the southwestern part of the Vaildai heights. The climate of the area is characterized by large fluctuations in climatic factors, and periodic moderate droughts in summer (Karpov and Shaposhnikov 1983; Fig. 1). Dominating soil types are podzol and bog-podzol soils (Sokolov 1949), with a relatively high groundwater level located within $2 \mathrm{~m}$ of the surface in the majority of the forest stands (Rode 1950). Soil within the study locations was poor podzolic gleyed Sphagnum soil with similar profiles among the locations.

The Sphagnum-Myrtillus stands studied (Table 1) occupied poorly drained mesodepressions and had canopies formed mainly by spruce and birch (Betula pubescens Ehrh.). The forest floor was dominated by Sphagnum girgensohnii Russ. and blueberry (Vaccinium myrtillus L.). Small-scale canopy windfall gaps were the most typical disturbance event in these stands (Drobyshev 1999).

\section{Methods}

\section{Climatic data}

Climatic data were obtained from the meteorological station of the reserve located about $4 \mathrm{~km}$ from the study site. Daily precipitation and temperature measurements were used to obtain monthly averages and, subsequently, cumulative values for various sets of spring and summer months. We calculated the Seljaninov hydrothermal coefficient (SHC; Shvidenko et al. 1998), a simple measure of humidity for the 4 months (April to July) when spruce growth mainly occurs. SHC was calculated as

$$
\mathrm{SHC}=\frac{\sum P \times 10}{\sum T}
$$

where $\sum T$ and $\sum P$ are the sums of temperature and precipitation for a time period, respectively. Data for the period 1971-1996 were utilized to compute long-term averages (Fig. 1).

\section{Sampling of spruce stems}

Sapling data for the under-canopy location were obtained by randomly selecting saplings in areas without distinguishable canopy gaps. Within disturbed patches the saplings were studied in two small gaps (122 and $167 \mathrm{~m}^{2}$ in size, respectively), one medium $\left(1050 \mathrm{~m}^{2}\right)$, and one large (about $2400 \mathrm{~m}^{2}$ ) gap. Data from the two small gaps were combined during analysis. The recorded gaps were chosen from amongst canopy gaps which complied with the following rules: $(i)$ the gap was located completely within the studied forest type; (ii) the disturbed contour had a recognizable border; (iii) the gap was at least $50 \mathrm{~m}$ away from the nearest glade. 
Fig. 1. Average sum of temperatures and precipitation for April-June 1991-1996. T and P are long-term averages for the sum of temperatures and sum of precipitation, respectively, for 1971-1996 (with no temperature data for 1975 and 1978). Error bars are SDs.

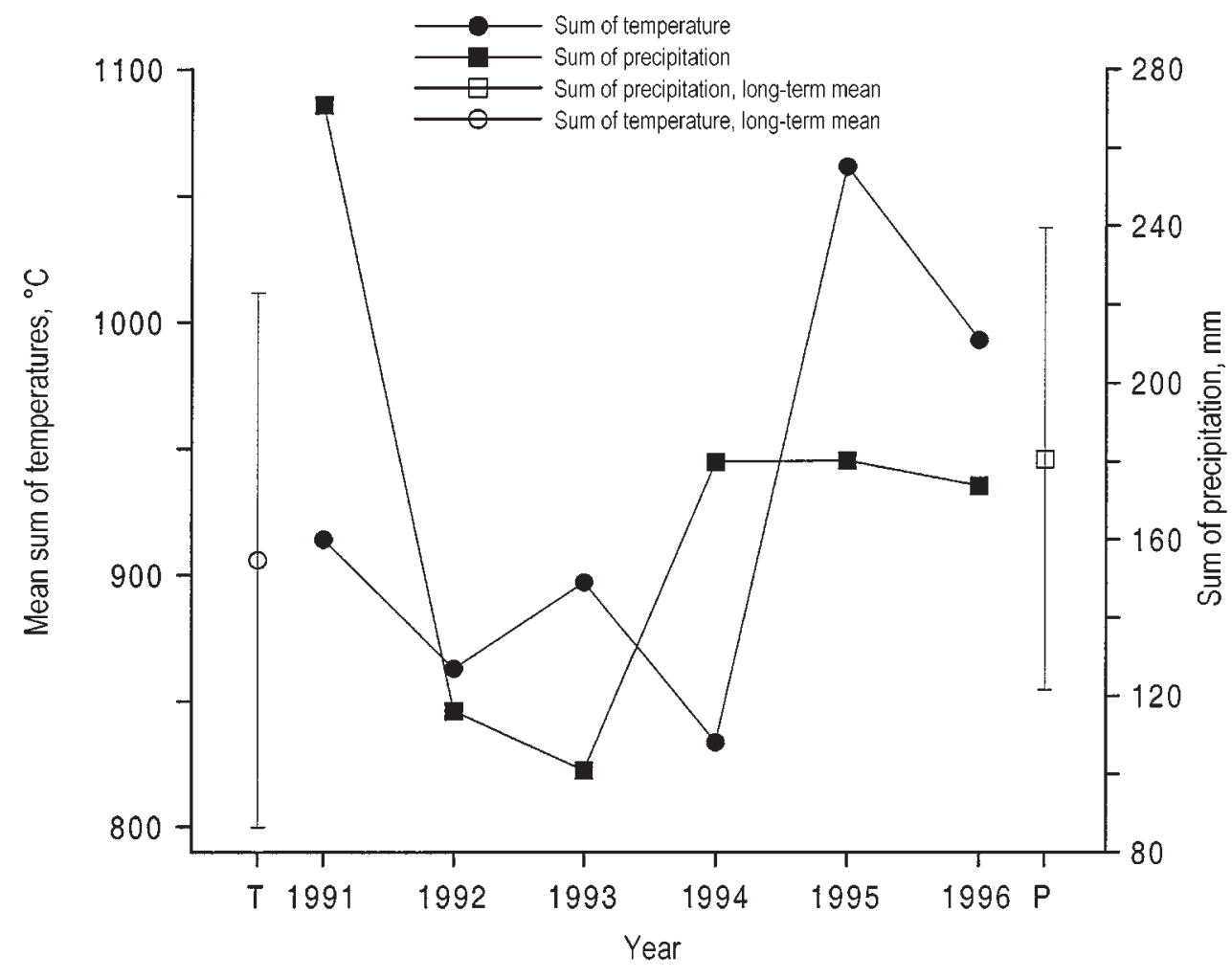

Table 1. Stand characteristics.

\begin{tabular}{ll}
\hline Average canopy height $(\mathrm{m})$ & $21.6 \pm 1.8$ \\
No. of canopy spruce trees/ha & $846 \pm 309$ \\
Average spruce DBH $(\mathrm{cm})$ & $26 \pm 7.1$ \\
Age of spruce trees in canopy (years) & $140(80-260)$ \\
\hline
\end{tabular}

Note: Values are means \pm SD, except for age which is mean with range given in parentheses. The data were obtained on four plots 150 $200 \mathrm{~m}^{2}$ in size, located under undisturbed canopy.

All locations were within an area with an approximate radius of $400 \mathrm{~m}$.

All disturbances were 9 years old. The annual increment of the terminal shoots on at least 25 stems were recorded retrospectively for 5 years (1992-1996). The number of stems sampled in each site was 26 under the intact tree canopy, 69 and 53 in the small gaps, 52 in the medium, and 25 in the large gap.

The stems sampled in gaps were growing within non-expanding gaps (i.e., defined by crown projections and not by tree bases; Runkle 1982) and at least $2 \mathrm{~m}$ from the crown projection of the nearest canopy tree. Thus, the effect of precipitation interception by tree crowns could be excluded for these stems. Possible effects of competitive interference (Golser and Hasenauer 1997) within the sapling cohort was addressed by sampling only stems having (i) no neighbors of similar or higher height within sapling crown projection and (ii) no more than one shorter neighbor within their crown projections.

In gaps, stems were sampled to represent the whole sapling pool of each gap and not particular within-gap locations. In small gaps, stems were sampled in four gap quarters (northwest, northeast, southwest, and southeast quarters). In the medium gap, sapling were recorded in the northwest and southeast gap portions as well as in the gap center. In the large gap, the data came from saplings from randomly chosen within-gap locations. Within each gap, only
Table 2. Age and height distributions of spruce saplings in different locations.

\begin{tabular}{llllllr}
\hline & \multicolumn{3}{l}{ Age (years) } & & \multicolumn{3}{l}{ Height $(\mathrm{m})$} & \\
\cline { 2 - 3 } & Mean & SD & & Mean & SD & $n$ \\
\hline Under canopy & 35.1 & 8.42 & & 1.28 & 0.87 & 26 \\
In small gaps & 20.0 & 5.68 & & 1.12 & 0.59 & 122 \\
In medium gap & 19.3 & 7.06 & & 1.48 & 0.73 & 52 \\
In large gap & 16.7 & 20.2 & & 1.33 & 0.74 & 25 \\
Combined for all locations & 21.2 & 11.1 & & 1.25 & 0.69 & 225 \\
\hline
\end{tabular}

stems growing at least $2-4 \mathrm{~m}$ from the nearest gap border were sampled.

All recorded saplings were between 0.3 and $3 \mathrm{~m}$ in height at the end of 1996. The low height limit of recorded spruce stems was set to $0.3 \mathrm{~m}$ above the ground to ensure the consideration of only wellestablished individuals. Their mortality has been found to be much lower compared with that of spruce seedlings (Karpov et al. 1983). Setting $3 \mathrm{~m}$ as the higher height limit helped include the majority of spruce saplings present in gaps at the moment of sampling. The study did not consider changes in height distribution of the whole sapling pool in a particular location but focused on climate $\times$ disturbance size $\times$ growth interactions within one cohort $(0.3-3 \mathrm{~m})$. Therefore, sampling was aimed at obtaining similar height distributions of recorded stems among locations. Only in one case (small vs. medium gaps) did the actual "availability" of stems with particular height lead to a significant difference in average sapling height between these locations (Table 2).

The terminal shoot increment was measured as the distance between the two nearest whorls on the leading branch of the sapling, with an accuracy of $\pm 1 \mathrm{~mm}$. Cores or cross sections were made at a height of $2-10 \mathrm{~cm}$ above the ground to obtain data on sapling 
Fig. 2. Relationship between cumulative 5-year increment and sapling height in 1992 for different locations.

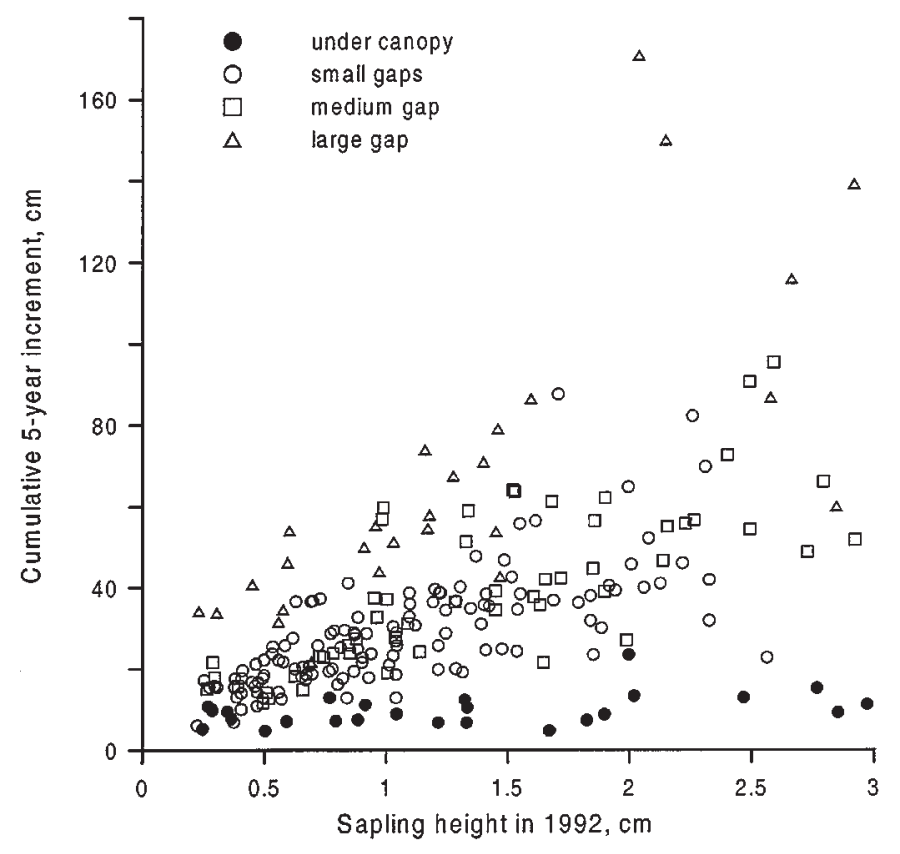

age, and to find the age of the canopy gap. The latter was estimated as the time since the last two to four fold enlargement of the annual growth ring.

\section{Statistics}

A Mann-Whitney $U$ test was used to compare age and height distribution of stems among different locations. To evaluate the relationship between growth rate, age and stem height, a Spearman partial correlation (Altman 1991) was computed for the 5-year cumulative terminal increment and the above-mentioned parameters.

To study sapling growth response to annual climatic variability, ANCOVA analysis with repeated measures design was applied with calendar years as the independent factor and terminal shoot increment as the dependent variable. Covariates included sapling age and height, and previous year growth. Additionally, MANOVA analysis was conducted with location and calendar years as independent factors. The increment data were natural log transformed to avoid correlation between means and SDs across cells.

The variability in the sapling growth rate was estimated by the coefficient of variation (CV) calculated in two ways: as annual variation observed within a particular sapling over a 5-year period (later referred to as "within-stem variation"), and variation due to different growth rates among saplings (later referred to as "withinlocation variation"). For the estimation of within-stem growth variation, CV was calculated for a 5-year period for each stem, and the obtained values were averaged for each location. In the case of within-location variation, single year and 5-year cumulative increments were used to obtain CVs for each location.

The drawbacks of the study were the lack of proper gap replication and the fact that only a 5-year period was considered. However, consistency of obtained results and presence of climatically contrasting years during the selected period helped partly to avoid these shortcomings.

\section{Results}

\section{Age and height distributions of saplings}

Sapling age decreased from under-canopy locations to large gaps (Table 2, Fig. 2), and the Mann-Whitney $U$ test
Table 3. Impact of height and age of the stem on cumulative 5 -year terminal increment as estimated by Spearman partial correlation coefficient.

\begin{tabular}{llc}
\hline Location & $R_{\mathrm{S}}$ with height & $R_{\mathrm{s}}$ with age \\
\hline Under canopy & $0.075(0.751)$ & $0.180(0.390)$ \\
Small gap & $0.783(<0.0001)$ & $-0.555(<0.0001)$ \\
Medium gap & $0.771(<0.0001)$ & $-0.185(0.188)$ \\
Large gap & $0.674(<0.001)$ & $-0.142(0.498)$ \\
\hline
\end{tabular}

Note: Values in parentheses are probabilities.

Table 4. Impact of sapling location and annual growth variation on terminal shoot growth: results of MANOVA analysis with age and height of saplings at 1992 as covariates.

\begin{tabular}{lrrl}
\hline Factors & \multicolumn{1}{l}{ MS } & \multicolumn{1}{l}{$F$} & \multicolumn{1}{l}{$p$} \\
\hline Location & 13.773 & 42.5 & $<0.0001$ \\
Annual variation & 2.772 & 35.2 & $<0.0001$ \\
Location + annual variation & 0.316 & 4.0 & $<0.0001$ \\
\hline
\end{tabular}

indicated significant differences between any pair of contrasts (with $p=0.034-0.0001$ ). The mean height and the distribution of heights were significantly different between small and medium gaps $(p=0.002)$. Although saplings were limited to individuals less than $3 \mathrm{~m}$ in height, gap size affected the mean height and the distributions of height; significant difference was observed between saplings in small and medium gaps $(p=0.002)$.

\section{Sapling growth at different locations}

In gaps the growth rate was closely related to the height of the stems (Table 3), whereas in most cases correlation between growth and stem age was insignificant.

Both factors, a sapling's location and annual growth variation, significantly influenced terminal shoot increment (Table 4). Judging by the MS and value of $F$ statistics, the location factor was of main importance for growth. Interaction of location and annual variability was also significant. However, it appeared to be the least important factor.

ANCOVA analysis revealed numerous highly significant differences in growth between years in a single location (Table 5, Fig. 3). In general, the growth pattern matched the one of SHC of the current season, whereas previous year SHC appeared not to fit the growth dynamics. Except within the large gap, growth was significantly greater in 1994 compared with 1993. In all locations except for the medium gap, years 1992 and 1994 had significantly different growth. Only in the medium gap was there a significant difference between years 1992 and 1993. Within the studied time frame, 1994 had the highest value of SHC and showed increased growth in the majority of locations. In contrast, the following year indicated a drop in both SHC value and growth rate in every location.

Growth variability, expressed as the coefficient of variation (CV), showed two opposite trends among the studied locations (Fig. 4). Within-stem annual variation decreased consistently from the under-canopy situation to the large gap. In contrast, growth variation among sampled stems in a particular location had a tendency to increase with increasing size of disturbance. We found no relationship between 
Table 5. Annual growth variation of the terminal shoot increment: results of ANCOVA analyses. Significance of post-hoc comparisons was checked by LSD test.

\begin{tabular}{|c|c|c|c|c|}
\hline Location & MS & $F$ & $p$ & $\begin{array}{l}\text { Years with significantly } \\
\text { different growth }\end{array}$ \\
\hline Under canopy & 1.049 & 4.95 & 0.001 & $\begin{array}{l}1992 \text { vs. } 1994,1996 \\
1993 \text { vs. } 1994,1996 \\
1994 \text { vs. } 1995 \\
1995 \text { vs. } 1996\end{array}$ \\
\hline Small gaps & 8.69 & 51.49 & $<0.0001$ & $\begin{array}{l}1992 \text { vs. } 1994,1995 \\
1993 \text { vs. } 1994,1995 \\
1994 \text { vs. } 1995,1996 \\
1995 \text { vs. } 1996\end{array}$ \\
\hline Medium gap & 3.24 & 29.4 & $<0.0001$ & $\begin{array}{l}1992 \text { vs. } 1993,1995,1996 \\
1993 \text { vs. } 1994,1995 \\
1994 \text { vs. } 1995,1996 \\
1995 \text { vs. } 1996\end{array}$ \\
\hline Large gap & 1.121 & 16.7 & $<0.0001$ & $\begin{array}{l}1992 \text { vs. } 1995,1996 \\
1993 \text { vs. } 1995,1996 \\
1994 \text { vs. } 1995,1996\end{array}$ \\
\hline
\end{tabular}

within-sapling variation and sapling age: coefficient of correlation was insignificant at all studied locations $(r=-0.168$, $0.115,0.013$, and 0.115 for under canopy and small, medium, and large gaps, respectively). Height also provided no significant impact on within-sapling variation $(r=-0.083$, $0.034,0.043$, and 0.284 for under canopy and small, medium, and large gaps, respectively).

\section{Discussion}

\section{Pattern of annual sapling growth}

Besides the positive allometric relationship between tree size and its growth rate, strong correlations between sapling height and their growth in gap suggested (i) greater resource availability for taller saplings (e.g., light) and (ii) taller saplings could be less suppressed than shorter ones. However, under the canopy, taller saplings did not necessarily receive more light, and the level of suppression could vary quite independently of sapling height.

After 4 years since a gap-formation episode, spruce saplings appeared to acclimate well to the changes in their environment, in particular increased light levels in the canopy gaps and higher water demand. Studied saplings showed greater growth in years with increased water availability. The study area was located close to the southern distribution limit of Sphagnum-Myrtillus stands (Tolmachov 1954), where water losses due to evapotranspiration apparently limits spruce growth (Abrazhko 1983a, 1983b). The positive correlation observed between water availability (represented as SHC dynamics) and growth is supported by similar conclusions from other studies (e.g., Devall et al. 1991; Le Goff and Ottorini 1993; Frolking et al. 1996).

Besides the direct relationship between precipitation and temperature, water availability for saplings should be also controlled by the size of canopy opening and underground interference between saplings and canopy trees (Karpov 1969). Size of canopy opening can be positively related with the amount of rainfall (Anderson et al. 1969; Rydgren 1996), especially with water availability in upper soil horizons (Nihlgård 1971), and negatively with the level of root interference between sapling and canopy trees. Changes in the water demand of canopy trees apparently follow the one of spruce saplings. Subsequently, the water uptake by trees can enhance the impact of dry years under the canopy and probably also in small and medium sized gaps, where one might expect belowground interference from trees around the gap (Parsons et al. 1994; Campbell et al. 1996).

Apparently, an increase in light levels in greater gaps is associated with a more favorable water balance of spruce saplings. This conclusion is supported by the observation that the size of a gap and soil moisture are positively correlated (Mladenoff 1987), and data from experimental studies suggesting that spruce saplings can successfully acclimate to the sudden changes in light or water conditions after formation of large gaps (Katrushenko 1965). However, extrapolation of this conclusion for the silvicultural implications should be done with caution; studies of the water regime of spruce sapling shoots before and after clear-cutting identified atmospheric evaporative demand and associated water stress (Sellin 1997), lower winter and spring temperatures and photoinhibition effects (Strand and Öquist 1985; Tucker et al. 1987) as important factors leading to growth retardation.

Little correspondence between previous year SHC and current year growth indicated that growth variation, measured as a function of elongation rate of the terminal shoot, was primarily determined by current-year conditions.

\section{Pattern of growth variation}

Growth variation originates from $(i)$ differences in sapling age and height distributions among locations, (ii) different degrees of environmental variability among locations, and (iii) differences in the sapling ability to respond to environmental fluctuations.

Despite differences in average age and, in one case, in average sapling height among locations (Table 2), these two factors appeared not to influence within-sapling growth variation 
Fig. 3. Sapling growth pattern in different locations and dynamics of Seljaninov hydrothermal coefficient (SHC) for the period 19921996.

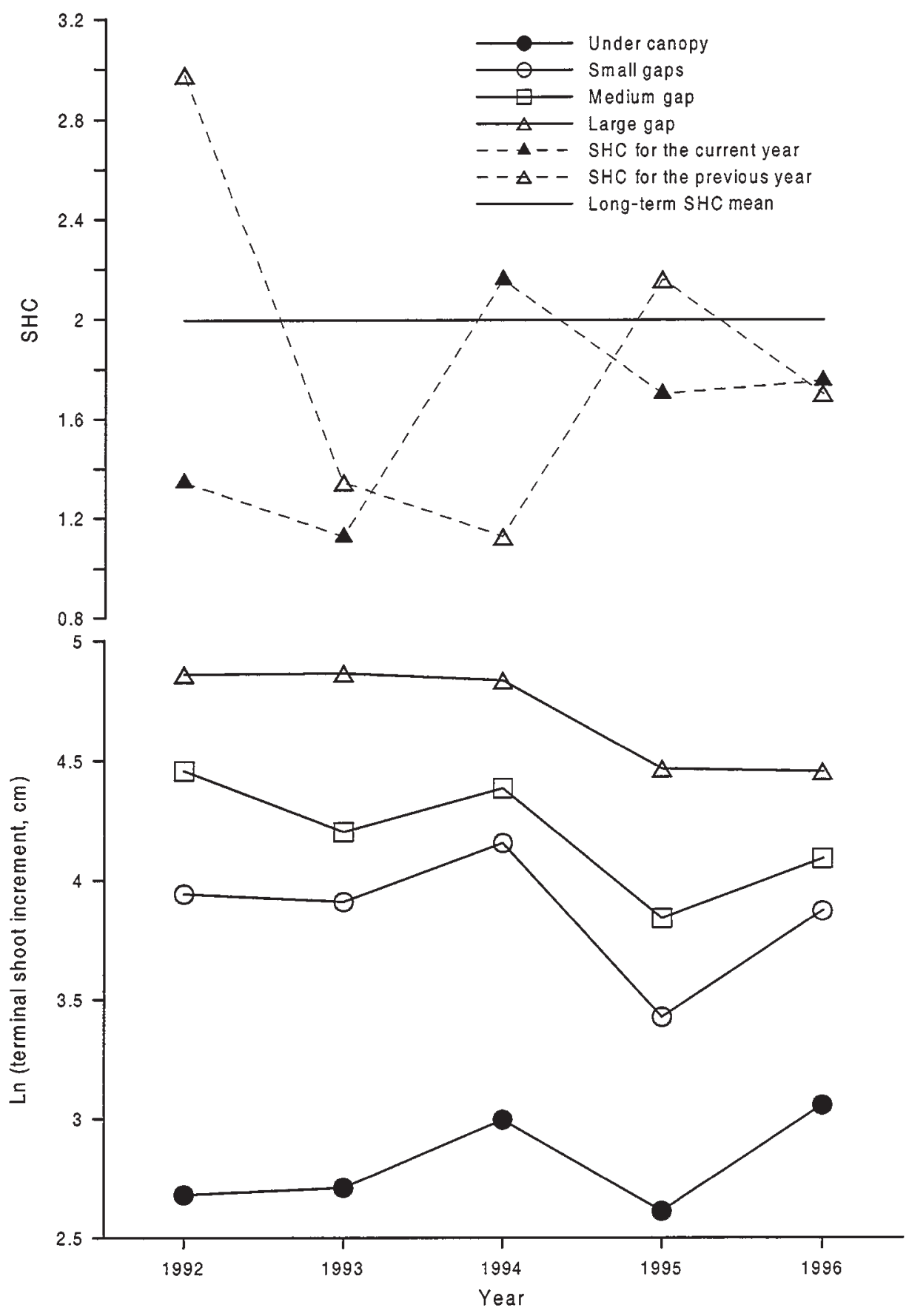

as indicated by low correlation coefficients between them and $\mathrm{CV}$ of growth. It also suggested that differences in average age among locations were probably not responsible for differences in within-sapling and within-site CVs. Another possible explanation relates $\mathrm{CV}$ dynamics with increased variation in stem age (that is, SD of stem age distribution). This alternative seemed not to be consistent with the observed changes in SD of age distributions (Table 3). In contrast with a monotonous increase in the $\mathrm{CV}$ of the growth rate (Fig. 4), the SD of age distribution dropped from the understory location to medium gaps, and only in the large gap did its value increase (Table 2). The same argument seemed appropriate to rule out the impact of height difference between medium and small gaps on CV dynamics.

It is likely that changes in environmental conditions and the ability of saplings to respond to them were the factors responsible for the observed trends. Because of higher air humidity, less light, and lower growth rate, saplings probably have a lower water demand under the canopy. Sapling evapotranspiration is apparently also reduced under the canopy; studies of the physiological characteristics of spruce needles have shown that their transpiration is strongly correlated with the amount of available light (Abrazhko 1983a). As a result, saplings might be less susceptible to microsite-specific 
Fig. 4. Within-stem and within-location variation of terminal shoot growth.

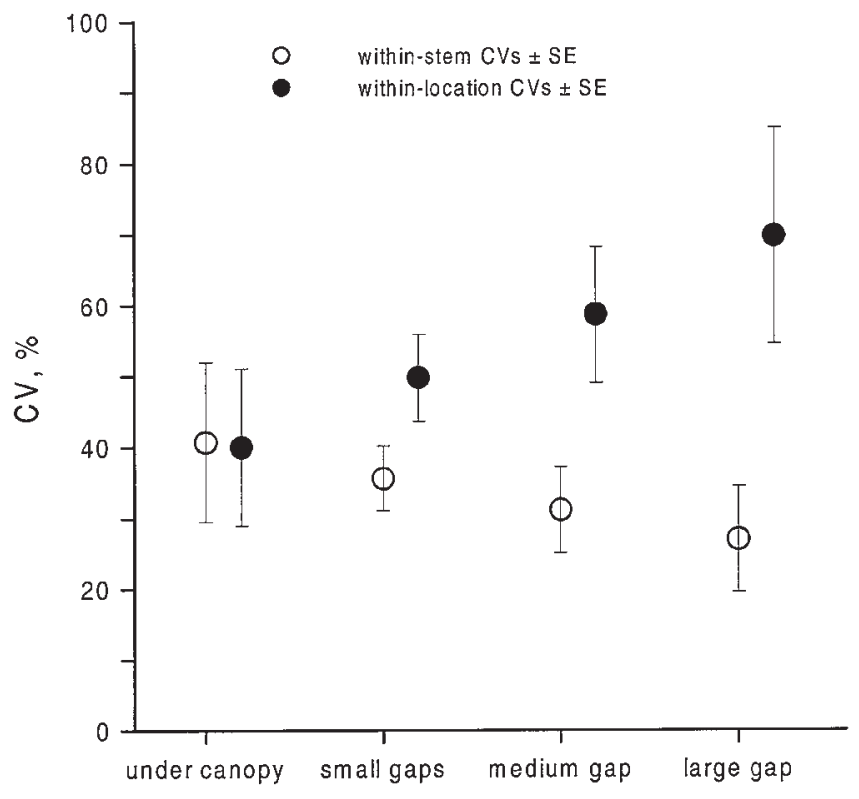

variation in water availability under a canopy than in a gap (Sipe and Bazzaz 1994). Additionally, increased size of disturbance is generally associated with greater variation in environmental heterogeneity within a disturbed patch (Gray and Spies 1996), e.g., variation in temperature (Mladenoff 1987; Sipe and Bazzaz 1994). The result of increased among-sapling growth variation in larger disturbances should be more pronounced differentiation (competitive asymmetry; Newton and Jolliffe 1998) of saplings in respect to height and, reversibly, future growth. It is important to note that the effect cannot be indirectly attributed to the close correlation between sapling height and its growth in gaps; we found no significant relationship between $\mathrm{CV}$ itself and height.

In case of an increase in within-stem variation, saplings under an intact canopy were characterized by higher sensitivity to annual climatic fluctuation. We speculate that the biomass accumulation rate can be positively connected with sapling ability to buffer environmental changes. Consequently, a sapling exhibited lower growth variability under more favorable growth conditions. This effect should be similar to one well known from dendroecological studies of trees whose growth is differentially limited by climate, socalled sensitive and complacent tree growth patterns (e.g., Schweingruber 1993).

\section{Conclusions}

The results obtained for a 5-year period suggest that differences in sapling location along a gradient of gap sizes are more important for the stem height growth than the yearly climatic variation (hypothesis 1) and that the relative importance of annual climatic variability, represented by dynamics of water availability, was negatively related to the size of canopy gaps (hypothesis 2). Within-stem and within-location variation appeared to be similar under the canopy, and both components of growth variability consistently changed over gradient of gap sizes (hypothesis 3); within-stem variation had a tendency to decrease in greater gaps, whereas withinlocation variation increased. Indirect evidence suggested that dynamics of within-stem variation reflected a positive relationship between the level of canopy disturbance and resource availability for saplings. Instead, changes in withinlocation variation was apparently caused by a positive relationship between the size of the disturbance and environmental heterogeneity within a disturbed patch. This effect should contribute to the process of sapling stratification and later widen the range of tree heights in the forest canopy. It seems to be of interest for future studies to include in the analysis a wider range of height cohorts, and to extend the time frame under consideration.

\section{Acknowledgements}

We are grateful to Dr. Eugene Shaposhnikov for allowing I.D. to carry out field studies in the Central Forest Biosphere State reserve. We thank Vadim Abrazhko for help and comments on early stages of the project, Ulf Stromberg for the statistical advice, Alistair Chapwick for the language corrections, and three anonymous reviewers for providing many helpful comments on earlier versions of the manuscript. Financial support for I.D. was partly provided by the Russian Fund of Basic Researchers (group grant No. 95-04-11307); a scholarship from The Swedish Institute, Stockholm; and fellowship from SUFOR Project, Lund University. I.D. thanks Maria Noskova for her assistance.

\section{References}

Abrams, M.D., and Orwig, D.A. 1995. Structure, radial growth dynamics and recent climatic variations of a 320-year-old Pinus rigida rock outcrop community. Oecologia, 101: 353-360.

Abrazhko, V.I. 1983a. Comparative studies of water regime in spruce tree stands. In Regulation factors of spruce forest ecosystems. [In Russian.] Edited by V.G. Karpov. Nauka, Leningrad. pp. $118-127$.

Abrazhko, V.I. 1983b. Peculiarities of water regime of trees. In Regulation factors of spruce forest ecosystems. [In Russian.] Edited by V.G. Karpov. Nauka, Leningrad. pp. 196-213.

Altman, D.G. 1991. Practical statistics for medical research. Chapman \& Hall, London.

Anderson, R.C., Loucks, O.L., and Swan, A.M. 1969. Herbaceous response to canopy cover, light intensity, and throughfall precipitation in coniferous forest. Ecology, 50: 255-263.

Busing, R.T., and White, P.S. 1997. Species diversity and smallscale disturbance in an old-growth temperate forest: A consideration of gap partitioning concepts. Oikos, 78: 562-568.

Campbell, J.J., Finer, L., and Messier, C. 1996. Does a $10 \times 10 \mathrm{~m}$ above-ground gap create a below-ground gap? In Abstracts of the 2nd International Workshop on Disturbance Dynamics in Boreal Forest, Aug. 1996, Rouyn-Noranda, Que. Edited by Y. Bergeron and G. Frisque. pp. 41-44. (Abstr.)

Canham, C.D. 1988. Growth and canopy architecture of shadetolerant trees: response to canopy gaps. Ecology, 69: 786-795.

Canham, C.D., and Marks, P.L. 1985. The response of woody plants to disturbance: patterns of establishment and growth. In The ecology of natural disturbance and patch dynamics. Edited by S.T.A. Pickett and P.S. White. Academic Press, New York. pp. 197-217. 
Clark, D.A., and Clark, D.B. 1994. Climate-induced annual variation in canopy tree growth in a Costa Rican tropical rain forest. J. Ecol. 82: 865-872.

Clinton, B.D., Boring, L.R., and Swank, W.T. 1993. Canopy gap characteristics and drought influences in oak forests of the Coweeta basin. Ecology, 74: 1551-1558.

Devall, M.S., Grender, J.M., and Koretz, J. 1991. Dendroecological analysis of a longleaf pine Pinus palustris forest in Mississippi. Vegetatio, 93: 1-8.

Drobyshev, I.V. 1999. Regeneration of Norway spruce in canopy gaps in Sphagnum-Myrtillus old-growth forests. For. Ecol. Manage. 115: 71-83.

Ettl, G.J., and Peterson, D.L. 1995. Growth responce of subalpine fir (Abies lasiocarpa) to climate in the Olympic Mountains, Washington, USA. Global Change Biol. 1: 213-230.

Fritts, H.C. 1974. Relationships of ring widths in arid-site conifers to variation in monthly temperature and precipitation. Ecol. Monogr. 44: 411-440.

Frolking, S., Goulden, M.L., Wofsy, S.C., Fan, S-M., Sutton, D.J., Munger, J.W., Bazzaz, A.M., Daube, B.C., Crill, P.M., Aber, J.D., Band, L.E., Wang, X., Savage, K., Moore, T., and Harriss, R.C. 1996. Modeling temporal variability in the carbon balance of a spruce/moss boreal forest. Global Change Biol. 2: 343-366.

Golser, M., and Hasenauer, H. 1997. Predicting juvenile tree height growth in uneven-aged mixed species stands in Austria. For. Ecol. Manage. 97: 139-152.

Gray, A.N., and Spies, T.A. 1996. Gap size, within-gap position and canopy structure effects on conifer seedling establishment. J. Ecol. 84: 635-645.

Hofgaard, A., Kullman, L., and Alexandersson, H. 1991. Response of old-growth montane Picea abies (L.) Karst. forest to climatic variability in northern Sweden. New Phytol. 119: 585-594.

Hogg, E.H. 1994. Climate and the southern limit of the western Canadian boreal forest. Can. J. For. Res. 24: 1835-1845.

Hytteborn, H., Packham, J.R., and Verwijst,T. 1987. Tree population dynamics, stand structure and species composition in the montane virgin forest of Vallibaecken, northern Sweden. Vegetatio, 72: 3-19.

Karpov, V.G. 1969. Experimental phytocoenology of dark coniferous forests. [In Russian.] Nauka, Leningrad.

Karpov, V.G., and Shaposhnikov, E.S. 1983. Spruce forests of the territory. In Regulation factors of spruce forest ecosystems. [In Russian.] Edited by V.G. Karpov. Nauka, Leningrad. pp. 7-34.

Katrushenko, I.V. 1965. On potential intensity of photosyntesis of spruce saplings under different light conditions. Bot. Zh. 50: 91-95.

Le Goff, N., and Ottorini, J-M. 1993. Thinning and climate effects on growth of beech (Fagus sylvatica L.) in experimental stands. For. Ecol. Manage. 62: 1-14.

Maherali, H., DeLucia, E.H., and Sipe, T.W. 1997. Hydraulic adjustment of maple saplings to canopy gap formation. Oecologia, 112: $472-480$.

Mladenoff, D.J. 1987. Dynamics of nitrogen mineralization and nitrification in hemlock and hardwood treefall gaps. Ecology, 68: 1171-1180.

Newton, P.F., and Jolliffe, P.A. 1998. Aboveground modular component responses to intraspecific competition within densitystressed black spurce stands. Can. J. For. Res. 28: 1587-1610.

Nihlgård, B. 1971. Pedological influence of spruce planted on former beech forest soils in Scania, South Sweden. Oikos, 22: 302-314.

Orwig, D.A., and Abrams, M.D. 1997. Variation in radial growth responses to drought among species, site and canopy strata. Trees, 11: 474-484.
Parsons, W.F.J., Parsons, S.L., Knight, D., and Miller, S.L. 1994. Root-gap dynamics in a lodgepole pine forest: ecomycorrhizal and nonmycorrhizal fine root activity and experimental gap formation. Can. J. For. Res. 24: 1531-1538.

Piutti, E., and Cescatti, A. 1997. A quantitative analysis of the interactions between climatic response and intraspecific competition in European beech. Can. J. For. Res. 27: 277-284.

Platt, W.J., and Strong, D.R. 1989. Gaps in forest ecology. Ecology, 70: 535 .

Rebertus, A.J., and Burns, B.R. 1997. The importance of gap processes in the development and maintenance of oak savannas and dry forests. J. Ecol. 85: 635-645.

Rode, A.A. 1950. Soil water regime of podzol, bog-podzol, and bog soils. [In Russian.] Proc. Dokuchaev Soil Inst. 52: 5-73.

Runkle, J.R. 1982. Patterns of disturbance in some old-growth mesic forests of eastern North America. Ecology, 63: 1533-1546.

Runkle, J.R. 1985. Disturbance regimes in temperate forests. In The ecology of natural disturbance and patch dynamics. Edited by S.T.A. Pickett and P.S. White. Academic Press, New York. pp. 13-33.

Rydgren, K. 1996. Vegetation-environment relationships of oldgrowth spruce forest vegetation in Ostmarka Nature Reserve, SE Norway, and comparison of three ordination methods. Nord. J. Bot. 16: 421-439.

Savage, M., Brown, P.M., and Feddema, J. 1996. The role of climate in a pine forest regeneration pulse in the southwestern United States. Ecoscience, 3: 310-318.

Schweingruber, H.F. 1993. Trees and wood in dendrochronology. Springer-Verlag, Berlin.

Shvidenko, A., Nilsson, S., Stolbovoi, V., and Wendt, D. 1998. Background information for carbon analysis of the Russian forest sector. IISA Rep. A-2361. Laxenburg, Austria.

Sipe, T.W., and Bazzaz, F.A. 1994. Gap partitioning among maples (Acer) in central New England: shoot architecture and photosynthesis. Ecology, 75: 2318-2332.

Sochava, V.B. 1956. Dark coniferous forests. In Vegetation cover of USSR. Explanatory text for geobotanical map of the USSR. Vol. 1. [In Russian.] Publishing House of Academy of Sciences of the USSR, Moscow, Leningrad. pp. 139-216.

Sokolov, K.M. 1949. Relief and quaternary deposits of Central Forest reserve. [In Russian.] Sci. Rec. Leningrad State Univ. Ser. Geogr. 124: 52-115.

Strand, M., and Öquist., G. 1985. Inhibition of photosynthesis by freezing temperatures and high light levels in cold-acclimated seedlings of Scotch pine (Pinus sylvestris): I. Effects on the light-limited and light-saturated rates of $\mathrm{CO}_{2}$ assimilation. Physiol. Plant. 64: 425-430.

Swetnam, T.W., and Betancourt, J.L. 1998. Mesoscale disturbance and ecological response to decadal climatic variability in the American Southwest. J. Clim. 11: 3128-3147.

Swetnam, T.W., and Lynch A.M. 1993. Multicentury, regional scale patterns of western spruce budworm outbreaks. Ecol. Monogr. 63: 399-424.

Sykes, M.T., and Prentice, I.C. 1996. Climate change, tree species distributions and forest dynamics: a case study in the mixed conifer/northern hardwoods zone of northern Europe. Clim. Change, 34: 161-177.

Tolmachov, A.I. 1954. On the history of appearance and succession of dark coniferous forests. [In Russian.] Izd-vo AN SSR, Moscow, Leningrad.

Tucker, G.F., Hinckley, T.M., Leverenz, J.W., and Jiang, S. 1997. Adjustments of foliar morphology in the acclimation of understory Pacific silver fir following clearcutting. For. Ecol. Manage. 21: 249-268. 
Veblen, T.T. 1986. Treefalls and the coexistence of conifers in subalpine forests of the central Rockies. Ecology, 67: 644-649.

Veenendaal, E.M., Swaine, M.D., Agyeman, V.K., Blay, D., Abebrese, I.K., and Mullins, C.E. 1996. Differences in plant and soil water relations in and around a forest gap in West Africa during the dry season may influence seedling establishment and survival. J. Ecol. 84: 83-90.

Villalba, R., and Veblen, T.T. 1994. Climatic influences on the growth of subalpine trees in the Colorado Front Range. Ecology, 75: $1450-1462$.

Villalba, R., Holmes, R.L., and Boninsegna, J.A. 1992. Spatial patterns of climate and tree growth variations in subtropical northwestern Argentina. J. Biogeogr. 19: 631-649.
Wayne, P.M., and Bazzaz, F.A. 1993. Birch seedling responses to daily time courses of light in experimental forest gaps and shadehouses. Ecology, 74: 1500-1515.

Yetter, T.C., and Runkle, J. R. 1986. Height growth rates of canopy tree species in southern Appalachian gaps. Castanea, 51: 157167.

Zhang, Q., Alfaro, I.R., and Hebda, R.J. 1999. Dendroecological studies of tree growth, climate and spruce beetle outbreaks in central British Columbia, Canada. For. Ecol. Manage. 121: 215225. 